\title{
The Emergence of American Formalism
}

\author{
DENNIS YI TENEN \\ Columbia University
}

"Enemy of fancy! Destroyer of wonders! Assassin of Prodigy!" Georges Polti's 1895 Les trente-six situations dramatiques was not received kindly. In the conclusion to the 1917 English edition of the work-advertised and reviewed widely in such North American publications as the Writer's Digest, the Editor, Printer's Ink Monthly, Scribner's Magazine, and the Author-Polti continued: "I hear myself accused, with much violence, of an intent to kill imagination. . . . Far from it"! ${ }^{1}$

Inspired by Carlo Gozzi, Johann Wolfgang von Goethe, and Friedrich Schiller, Polti based his taxonomy of dramatic situations, or plot devices, on some twelve hundred examples from ancient and modern literature, including the "principal dramas of China, of India, of Judea, and needless to say, of the Greek theater." He hoped that his archetypes would function as diagnostic tools. Which plots are the "most neglected and which the most used, in each epoch, genre, school, author?" he asked, and "What are the reasons for these preferences"? ${ }^{2}$ His book concluded not only with a defense of imagination but also with an offer to generate "ten thousand scenarios totally different from those used repeatedly upon our stage in the last fifty years." "I will deliver a thousand in eight days," he wrote: "Prices are quoted on single dozens. Write or call, No. 19, Passage de l'Elysee des Beaux-Arts."3

Polti's views were as popular as they were controversial. For a scholar of literary history, the Thirty-Six Dramatic Situations prefigures later structural studies of narrative by, among others, Vladimir Propp and Claude LeviStrauss. Its first English-language review appeared in the Nation in 1895. The Editor began advertising a translation by Lucille Ray in 1915. One could find it for sale in the back pages of literary periodicals well into the 1960s,

1. Georges Polti and Lucille Ray, The Thirty-Six Dramatic Situations (Ridgewood, NJ: Editor, 1917), 134.

2. Ibid., 13-14.

3. Ibid., 134.

(C) 2019 by The University of Chicago. All rights reserved. 0026-8232/2019/11702-0006\$10.00 
which gives us an indication of its influence and staying power. ${ }^{4}$ Yet, I found Polti almost entirely absent from the scholarly record. At first, I viewed his work as an anomaly, too early for its time perhaps and too inconsequential. A thread of references in the archive soon led me to a whole tapestry of similar late nineteenth- and early twentieth-century volumes in the American letters, such as William Wallace Cook's Plotto (1928) and Wycliffe A. Hill's The Plot Genie (1936). The latter volume even contained a paper-mechanical device called the Plot Robot, "designed to serve the purpose of giving the writer or author a definite and arbitrary assignment of a number of elements comprising a plot outline." ${ }^{5}$

With time, I understood these materials to be an integral part of the industrial age, which brought with it a reconfiguration of the literary sphere. They attest to a longue durée trend in the automation of creative labor. By the first few decades of the twentieth century, the use of writers' aids akin to Polti's Dramatic Situations was part of mainstream writing culture. Plot genies and plot robots led me to collections in the Library of Congress, the New York Public Library, and the Margaret Herrick Library in Beverly Hills, where I discovered dozens of similar volumes that anticipate many of the insights that we commonly associate with the Russian and French branches of formalism and structuralism.

The school of American formalism, as I propose to call it, differed from its European counterparts in being addressed primarily to the purposes of composition rather than analysis. It was a school, and not merely a genre or a style, in the sense that its members shared both intellectual and institutional affinities. ${ }^{6}$ The school produced literary works that were structurally similar, advancing also a system of common ideas and practices, propagated on the pages of numerous professional publications, in trade unions, and in actual schools. It was further a school of formalism not only in the literary-theoretical sense-manifested in preference for terms such as form, function, structure, technique, method, organizing principle, or mechanism ${ }^{7}$ - but also more broadly, relating to the translation of abstract, often nebulous concepts, such as genius and creativity, into a set

4. See, e.g., Writer 80 (1967): 39, 49, 57.

5. Wycliffe A. Hill, The Plot Genie Index: Comedy (Hollywood, CA: Gagnon, 1931).

6. Diana Crane, Invisible Colleges: Diffusion of Knowledge in Scientific Communities (University of Chicago Press, 1972), 85-88; Paul DiMaggio, "Classification in Art," American Sociological Review 52, no. 4 (August 1987): 440-55; and Scott Frickel and Neil Gross, "A General Theory of Scientific/Intellectual Movements,” American Sociological Review 70, no. 2 (April 2005): 205-8.

7. See Victor Erlich, "Russian Formalism," Iournal of the History of Ideas 34, no. 4 (OctoberDecember 1973): 627-38; Peter Steiner, Russian Formalism: A Metapoetics (Ithaca, NY: Cornell University Press, 1984; and Raymond Williams, Keywords: A Vocabulary of Culture and Society (Oxford University Press, 1985), 137-40. 
of concrete physical operations or procedures. ${ }^{8}$ It was finally an American school of formalism not because its practitioners were isolated from their Continental counterparts - the aforementioned popularity of Polti in translation attests otherwise, as do the contemporaneous developments in the German, Russian, and British traditions ${ }^{9}$ - but because of its sheer scope and scale in the United States. In the words of one contemporary: "In those days I was rigidly following the rules of what I call the [name of the journal omitted] school of the American short story.... Stories of the school which it dominated were all like Fords. They were of limited horsepower, neat, trim, and shiny, taking up very little road space, structurally correct and all following the blueprint without the slightest deviation." ${ }^{10}$ Although we do not have a record of the omitted publication, the evidence suggests a significant body of work perceived as a distinct movement by its contemporaries. The archive I have assembled here shows that the development of techniques for mass literary production predated its academic institutionalization in the postwar period. Institutionalization began in professional journals, associations, and textbooks aimed at the expanding writers' market at the turn of the twentieth century. The American formalists formed a school figuratively to the extent of their shared intellectual commitment and literally in that they founded correspondence schools, sought pupils, and wrote textbooks containing a programmatic articulation of their curriculum.

My methods in this study are primarily descriptive: I collect, describe, and document a preponderance of primary materials, which by their very weight and consistency would make what was before an overlooked moment in literary history seem obvious in retrospect. Studies of labor in literature tend to resolve into thematic studies of labor in representation. A true sociology of literature would strive to connect representational content with its institutional, economic, and technological contexts. ${ }^{11}$ The

8. Percy Williams Bridgman, The Logic of Modern Physics (New York, NY: Macmillan, 1927), 5-7; and Norman K. Denzin, The Research Act: A Theoretical Introduction to Sociological Methods (Chicago: Aldine, 1970), 14-19.

9. See, e.g., Oskar Walzel, Gehalt und Gestalt im Kunstwerk des Dichters (Berlin: Athenaion, 1900); Heinrich Wölfflin, Kunstgeschichtliche Grundbegriffe: Das Problem der Stilentwicklung in der neueren Kunst (München: Bruckmann, 1915); Percy Lubbock, The Craft of Fiction (London: Cape, 1921); E. M. Forster, Aspects of the Novel (New York, NY: Harcourt Brace, 1927); and Vladimir Propp, Morphology of the Folktale, trans. Laurence Scott (Austin, TX: American Folklore Society, University of Texas Press, 1968).

10. Arthur Sullivant Hoffman, The Writing of Fiction (New York: Norton, 1934), 40.

11. For an important thematic study of material production in the modernist imagination see Douglas Mao, Solid Objects: Modernism and the Test of Production (Princeton University Press, 1998). In the emphasis on labor I follow the programmatic, if brief, note by Boris Arvatov, who wrote: "Where a bourgeois theory of literature investigated either authors, or their works, or more broadly the development of style, a Marxist theory of literature should be 
American formalist archive gives us the means to study the propagation of reified literary forms, in the process of sedimentation from the realm of the ideal into praxis, as evidenced on the pages of numerous "how-to" manuals. By such means, we are able to recover a thick description of authorial labor, which transforms generalized templates-formulas and archetypes - into specifically instantiated works and objects. ${ }^{12}$

The formalization of literary labor at the turn of the twentieth century was precipitated by the rapid expansion of the literary sphere: the rise in literacy rates, the public libraries movement, and the growing popularity of new media such as radio, theater, and cinema. "The production of more than thirty thousand motion pictures yearly, in America alone, shows the tremendous need for good dramatic material," a successful Hollywood screenwriter wrote for those just entering the profession in $1915 .{ }^{13}$ This expanded market now included new reading and, crucially, new writing publics previously excluded from participation. The influx of inexperienced practitioners into a lucrative field entailed a palpable decline in the overall quality of material, felt most keenly by the gatekeepers of culture-critics, editors, and acquisition managers - who would often themselves become the workshop instructors and authors of manuals geared toward the novice. The American school was thus remarkable for exhibiting the dynamics of upward social mobility. It was a formalism that was a product of popular culture first and an intellectual academic movement second. Case studies that comprise the bulk of this article therefore often begin at the low- and middlebrow periphery of culture and move to its high-status center: from Midwestern presses to the coasts, from public lectures to institutional curricula, and from Hollywood to Harvard.

The American formalism that I uncovered in the archive is ultimately a species of an industrial modernism. Literary modernism means different things to different people. Some conflate it with the experimental and densely intertextual works by the likes of James Joyce, Ezra Pound, and

concerned with the organization of literary labor, in the sense of authorship as a social and professional activity. From this perspective, utilitarian literary art can be seen, at its maximal limits, as a collective and highly-technological manufacture of literary value" ("Utilitarianism in Literature [Utilitarizm V Literature],” October [Oktiabr'], no. 12 [December 1925]: 101; my translation).

12. A history of writing programs similarly requires an account of poetics. In this I concur with Paul Dawson, who asserts, "Writing drew upon a critical tradition, a poetics rather than a rhetoric, and thus developed out of Literary Studies rather than composition" (Creative Writing and the New Humanities [New York: Routledge, 2005], 60). See also Andrew Levy, The Culture and Commerce of the American Short Story (New York: Cambridge University Press, 1993); and David Gershom Myers, The Elephants Teach: Creative Writing since 1880 (University of Chicago Press, 1996).

13. Eustace Hale Ball, Photoplay Scenarios: How to Write and Sell Them (New York: Hearst's International Library, 1915), xi. 
Virginia Woolf. For others modernism conjures the existential dread of Friedrich Nietzsche and Søren Kierkegaard, the economics of Karl Marx and John Maynard Keynes, the evolutionary biologies of Jean-Baptiste Lamarck and Charles Darwin, the autoerotic technological fetishism of Filippo Marinetti and Vladimir Mayakovsky, the psychology of Sigmund Freud, or the physics of Albert Einstein. However, this conventional historiography has been rightly shown to be too narrowly concerned with Europe, too rarefied, too hegemonic, too male, and too white. A field of peripheral modernisms blooms - global, "bad," immigrant, queer, black-to show how incomplete the textbook account is and how comparatively small its welltrampled patch. ${ }^{14}$

I would like to add another perspective on this verdant expanse by considering modernism not only as a rejection of something - be it Romanticism, realism, the Enlightenment, reason, capitalism, or tradition-but as an embrace of industrialization. If "hostility to mass culture" was modernism's "defining trait," 15 this essay joins an alternative tradition, which sees modernism in furtherance of mass culture and by the means of mass manufacture. ${ }^{16}$ And if we have failed to perceive the impact of labor automation in the literary-cultural sphere, it is because we rarely think of writers or indeed thinkers as members of the working class. From this vantage, technology is too often cast as a boogeyman advancing to transform the craft of a smith, a seamstress, or a cobbler but not the labor conditions of a journalist, stockbroker, teacher, attorney, or scholar. In casting ourselves in the role of the resistance, we neglect to look at our own means of production - pen and paper — which were also irrevocably altered by the advance of industrialization.

Nothing as obvious as a conveyor belt confronts a literary historian. The indirect effects of cultural automation become more apparent only in retrospect. Consider, for the sake of a rough comparison, the complete works of Alexandre Dumas (the senior), one of the nineteenth century's most prolific authors, which span some sixty plays and about as many

14. Werner Sollors, "Ethnic Modernism, 1910-1950," American Literary History 15, no. 1 (Spring 2003): 70-77; Douglas Mao and Rebecca L. Walkowitz, eds., Bad Modernisms (Durham, NC: Duke University Press, 2010); Miriam Thaggert, Images of Black Modernism: Verbal and Visual Strategies of the Harlem Renaissance (Boston: University of Massachusetts Press, 2010); and Heather Love, "Introduction: Modernism at Night," PMLA 124, no. 3 (May 2009): 74448.

15. Lawrence S. Rainey, Institutions of Modernism: Literary Elites and Public Culture (New Haven, CT: Yale University Press, 1998), 2.

16. See, e.g., Mark S. Morrisson, The Public Face of Modernism: Little Magazines, Audiences, and Reception, 1905-1920 (Madison: University of Wisconsin Press, 2001); Paula Rabinowitz, Black and White and Noir: America's Pulp Modernism (New York: Columbia University Press, 2002); and David M. Earle, Re-covering Modernism: Pulps, Paperbacks, and the Prejudice of Form (Burlington, VT: Routledge, 2009). 
novels, several written with the aid of a ghostwriter. ${ }^{17}$ Tolstoy's output similarly resulted in a dozen or so novels and novellas among other literary miscellany. Dickens and Dostoevsky, who wrote serially for periodicals, penned just under twenty novels and novellas each and were considered prolific by the time's standards. ${ }^{18}$

By contrast, many popular writers in the first half of the twentieth century routinely wrote hundreds of novels and thousands of short stories. Georges Simenon, the Belgian writer of detective fiction, published several hundred novels. ${ }^{19}$ The Spanish author of romance novels, Corín Tellado, authored some four thousand long-form titles. ${ }^{20}$ Edward L. Stratemeyer, the author-producer behind such massively popular syndicates as The Rover Boys and Nancy Drew, released thousands of volumes. ${ }^{21}$ Paul Little, who wrote historical and pornographic fiction under many pseudonyms, produced more than seven hundred novels. ${ }^{22}$ The British writer L. T. Meade (Elizabeth Meade Smith), the author of $A$ World of Girls (1886), wrote more than three hundred mysteries, romance novels, and works of young adult

17. Hubert Jerningham, "Alexandre Dumas," Modern Language Quarterly 7, no. 2 (October 1904): 73-80; and Jane C. Ginsburg, "The Author's Name as a Trademark: A Perverse Perspective on the Moral Right of Paternity," Cardozo Arts and Entertainment Law Journal 23, no. 2 (2005): 379-89.

18. For example, the 1885 Russian-language critical commentary on Dostoevsky's work contains a long discussion on the view commonly held at the time that Dostoevsky was "prolific but lacks in talent" (Vasilii Zelinskii, Istoriko-Kriticheskii Kommentarii K Sochineniiam F. M. Dostoevskogo: Sbornik Kritik [Collection of criticism on the work of F. M. Dostoevsky] [Moscow, 1885], 134). "He was a prolific and rapid writer," Julius Meier-Graefe wrote about Dostoevsky in 1928 (Dostoevsky: The Man and His Work [New York: Routledge \& Sons, 1928], 13). The "prolific pen of Dickens" was abundant enough in print as to become a cliche. See "Reviews," Athenaeum: Journal of Literature, Science, the Fine Arts, Music and the Drama, December 1846; Frederic George Kitton, Charles Dickens by Pen and Pencil: Including Anecdotes and Reminiscences Collected from His Friends and Contemporaries (London, 1890), 98; Gerald Giles Grubb, "Dickens' Pattern of Weekly Serialization," ELH 9, no. 2 (June 1942): 141-56; Archibald Cary Coolidge, Charles Dickens as Serial Novelist (Ames: Iowa State University Press, 1967); and Nicola Bradbury, "Dickens and the Form of the Novel," in The Cambridge Companion to Charles Dickens, ed. John O. Jordan (Cambridge University Press, 2001), 152-66.

19. Pierre Assouline, Simenon: A Biography, trans. Jon Rothschild (New York: Knopf, 1997).

20. Michael Eaude, "Corín Tellado: Prolific Spanish Romantic Novelist," Guardian, May 4, 2009, https://web.archive.org/save/https://www.theguardian.com/books/2009/may /04/obituary-corin-tellado.

21. Deidre A. Johnson, Stratemeyer Pseudonyms and Series Books: An Annotated Checklist of Stratemeyer and Stratemeyer Syndicate Publications (Westport, CT: Greenwood, 1982); and Carol Billman, The Secret of the Stratemeyer Syndicate: Nancy Drew, the Hardy Boys and the Million Dollar Fiction Factory (New York: Ungar, 1986).

22. Kenan Heise, "Paul Little, 72, Author of More Than 700 Novels," Chicago Tribune, June 23, 1987, https://web.archive.org/save/https://www.chicagotribune.com/news/ct -xpm-1987-06-23-8702160020-story.html. 
fiction. ${ }^{23}$ Although one can find a few similarly prolific writers in prior times, this level of productivity is typical of the period.

Consider a few supplementary metrics. The total number of titles published in the United Kingdom grew from roughly three thousand in the 1840 s to ten thousand in the $1900 \mathrm{~s} .{ }^{24}$ According to my own figures, based on tabulations from the American Catalogue of Books in Print, the total number of titles printed in the United States (including translations and reprints) went from around two thousand in 1876 to seventeen thousand in the 1930s, a near ten-fold increase. ${ }^{25}$ True figures were likely higher, because pulp and yellow fiction in general were not well reflected in the official record. For example, in 1928 the Writer's Digest mentioned one popular pulp fiction printing house, Street \& Smith, receiving "close on nine hundred thousand manuscripts a year." "Fiction House buys nearly a million words a month for their various pulp fiction magazines," boasted another editor on the pages of the Writer's Digest in 1930. "A lot of our writers draw real pay from this office," he continued. "Over fifteen get more than $\$ 5,000$ a year." ${ }^{27}$ At the "fair average" of a penny per word, this meant that many Fiction House authors wrote on the order of half a million words per year, a volume equivalent to five lengthy novels annually. ${ }^{28}$

What factors can explain such a "seismic shift" in literary production?29 Rising literacy rates, which imply an increase in demand, tell only a part of the story, as does Hollywood's growing appetite for “photoplays.” Literacy rates in England and the United States did not change signficantly in the

23. Janis Dawson, “Write a Little Bit Every Day”: L. T. Meade, Self-Representation, and the Professional Woman Writer," Victorian Review 35, no. 1 (Spring 2009): 132.

24. Simon Eliot, Some Patterns and Trends in British Publishing, 1800-1919 (London: Bibliographical Society, 1994), 7; and Patrick Scott Belk, Empires of Print: Adventure Fiction in the Magazines, 1899-1919 (New York: Routledge, 2017), 12, appendix A.

25. Frederick Leypoldt, Lynds E. Jones, A. I. Appleton, and R. R. Bowker, The American Catalogue of Books in Print and for Sale (Including Reprints and Importations), 1876-1910, 9 vols. in 13 (New York: Smith, 1941).

26. John Locke, ed., Pulp Fictioneers: Adventures in the Storytelling Business (Silver Spring, MD: Adventure House, 2004), 13.

27. Ibid., 29

28. See, e.g., the "American Market" column in the February 1, 1907, issue of the Author: "Rates of payment vary from half a cent per word for the pot-boiling serial to almost anything a word for the desirable short story: a fair average for an unknown writer might be struck at one cent a word for serial work, with book rights reserved by the author, and from three to five cents a word for good short stories" (128). In his 1909 "A Municipal Report," O. Henry tells the story of a New York literary agent on a mission to Nashville, Tennessee with the purpose of contracting an unknown but promising essayist "at two cents a word before some other publisher offered her ten or twenty." They draw up a contract at eight cents, which the New York office considers a steal (“A Municipal Report," Hampton's Magazine, November 1909, 602, 607).

29. Belk, Empires of Print, 1. 
first half of the twentieth century, the period roughly corresponding to the rapid expansion of the literary sphere in the United States..$^{30}$ Instead, literacy increased sharply much earlier, in the second half of the nineteenth century, where its impact on authorial production was modest at best. ${ }^{31}$ Literacy cannot be shown to have a linear effect on print culture, as one may be tempted to assume. In the words of Simon Eliot, one of the foremost commentators on the British print market, "There was no steady, constant incline [in new and reprinted titles] leading from the slough of early industrial times to the sunny uplands of the almost fullyliterate twentieth century." 32 Instead, the publishing industry seems to have expanded in sudden rushes and spurts, which do not neatly correspond to the rise of literacy rates.

We can also surmise that with all other factors remaining the same, increased demand should have, by the basics of economic theory, resulted in higher wages for producers and higher prices for consumers. Book markets tell another story: the prices for print materials fell. For much of the nineteenth century, the cost of a novel (commonly published in several volumes] was around a guinea and a half, which equates to more than US $\$ 200$ today. ${ }^{33}$ Cheaper "yellowback" reprints at a few shillings per novel became more common by the 1870 s and 1880 s. At a cost of twenty to forty dollars in today's currency they represented a ten-fold decrease in price from the previous era. ${ }^{34}$ American pulps in the 1910s brought the

30. Lawrence C. Stedman and Carl F. Kaestle, "Literacy and Reading Performance in the United States, from 1880 to the Present," Reading Research Ouarterly 22, no. 1 (Winter 1987): 14.

31. Carl F. Kaestle, Literacy in the United States: Readers and Reading since 1880 (New Haven, CT: Yale University Press, 1992), 18; Harvey Graff, The Literacy Myth: Cultural Integration and Social Structure in the Nineteenth Century (New Brunswick, NJ: Transaction, 1991); and Edward Gordon and Elaine Gordon, Literacy in America: Historic Journey and Contemporary Solutions (Westport, CT: Praeger, 2003).

32. Eliot, Some Patterns and Trends in British Publishing, 8.

33. See J. A. Sutherland, Victorian Novelists and Publishers (London: Bloomsbury, 2014), 15; Leah Price, How to Do Things with Books in Victorian Britain (Princeton University Press, 2012), 168. To convert guineas into US currency I use the method suggested by Eric W. Nye in his "Determining Historical Monetary Values" and supplementary materials covered by Robert Twigger, Inflation: The Value of the Pound, 1750-1996 (London: House of Commons Library, 1997); L. E. Davis and J. R. T. Hughes, "A Dollar-Sterling Exchange, 18031895," Economic History Review 13, no. 1 (1960): 52-78; Eric W. Nye, "Coleridge and the Publishers: Twelve New Manuscripts," Modern Philology 87, no. 1 (August 1989): 51-72; and John McCusker, How Much Is That in Real Money?: A Historical Commodity Price Index for Use as a Deflator of Money Values in the Economy of the United States (Worcester, MA: American Antiquarian Society, 2002). Although all such comparisons are made difficult by the vicissitudes of history - the change in material underlying material conditions makes all surface comparison one of apples to oranges - the overall trend in falling prices per novel is undeniable and well documented.

34. George Locke, "Wells in Three Volumes? A Sketch of British Publishing in the 19th Century," Science Fiction Studies 3, no. 3 (November 1976): 282-86; Sutherland, Victorian Novelists 
cost of a paperback down to anywhere between 5 and 30 cents or only a few dollars in today's currency, another ten-fold decrease in book prices within several decades. ${ }^{35}$

Author wages also fell during the same period. At the midcentury stage of his career Charles Dickens garnered somewhere between one and two British pounds per page for his serial fiction, a sum in the vicinity of US $\$ 200$ today, which reckons to about a contemporary dollar per word. ${ }^{36}$ By the 1930s, a successful American author would be lucky to expect a few cents, or a few dimes per word in today's currency. ${ }^{37}$ Pulp rates ranged from a halfpenny to 35 cents or more, depending on author and publicationand that during an economically volatile time around the Great Depression. Instead of rising, as would be expected if demand alone was the cause of the changes, both the price of print and author wages declined by several orders of magnitude. ${ }^{38}$ These trends indicate that literacy and the corresponding increased demand for reading materials cannot alone explain the rapid expansion of the book market. Falling prices and wages also suggest an increase in literary production and the subsequent growth in the supply of reading material.

In viewing the print market from the perspective of labor history, I build on the work of contemporary sociologists of literature such as Merve Emre, James English, Nathalie Heinich, Amy Hungerford, and Mark McGurl. McGurl in particular has called for a historiography of writing programs in his monograph The Program Era (2009). Where McGurl's work emphasizes literary programs as social institutions, I understand programmatic writing also in the sense of "rules or heuristics for composition."

and Publishers, 7-98; and David Deirde, introduction to The Cambridge Companion to the Victorian Novel, ed. Deidre (Cambridge University Press, 2012), 37.

35. Wallace Bamber, "Let's Face the Facts, Pulp Writers!," in Locke, Pulp Fictioneers, 49-54.

36. Dickens, it bears mentioning to avoid a common confusion, was not paid by the word. His income included royalty and per-installment payments, annual salaries, editorial fees, and bonuses. I am counting only his per-installment payments, which were not exuberant. The per-word calculations are estimates done for the sake of comparison. Dickens is good marker of comparison for us because the metaliterary details of his professional life are well established and because he was an early pioneer of serial fiction. See also Robert L. Patten, Charles Dickens and "Boz": The Birth of the Industrial-Age Author (Cambridge University Press, 2012), 88, 350.

37. Wallace Bamber, the editor of Far East Adventure Stories, wrote the following for Author and Journalist trade magazine in 1932: "It must be admitted that some of the present pulps that sell for 25 cents are worth it. Some of them contain editorial matter that has cost them as high as 10 cents a word, and they have to get more for their product than some of those pulp that have a selling price of 25 cents and never pay more than 2 cents a word for editorial content" ("Let's Face the Facts, Pulp Writers!," 53). I am also basing the estimates on my review of "The Writer's Market" column in the Writer's Digest ca. 1920-40s.

38. I extend my gratitude to John Tofanelli, Librarian for British and American History and Literature at Columbia University Libraries, for bibliographic support in this section. 
The two senses overlap in that both university writing programs and formulaic composition aids presuppose the possibility of teachable technique. McGurl usually discusses technique in terms of "craft" or, as he calls it, the "lore of literary tradition." 39 We must believe, however, that the institution of writing programs also involved the passage of transmitted technique more tangible than the notion of lore, primarily an oral tradition, would imply. While reading E. H. Gombrich's 1959 classic Art and Illusion, I was struck by his commentary on the transmission of stylistic templates in the visual arts. In looking at art textbooks - the "dreary and melancholy methods by which Victorian boys were taught to draw the schema of a leaf"-Gombrich was able to recover the tangible, formal features of a period, usually explained in more idealized, Hegelian terms such as style or spirit of the times. "The metaphysics of art should always be supplanted by an analysis of its practice, notably the practice of teaching," Gombrich concluded. ${ }^{40}$

But where can we observe the transmission of literary technique? McGurl's programmatic era begins in the aftermath of the World War II, with the establishment of American creative writing programs. I place it much earlier, at the origins of correspondence schools and professional journals aimed at the dissemination of reproducible technique. Scholars such as David Searle, Lawrence Rainey, and Paula Rabinowitz have urged us to look to mass literary periodicals for alternative histories of modernism, where I also find a rich archive of instructional materials, manuals, and writers' aids. The archive shows that at the end of the nineteenth century, some American (and to a lesser extent, European) authors began to conceive of their work in terms of industrial manufacture. This shift involved a conception of the creative process in language that emphasized technique over talent, form over content, and style over sentiment. In aggregate, the diverse practitioners of this movement shaped a distinctly American school of formalism, which - although deriving from the same sources - predated both Russian formalism and French structuralism, in full stride by the early and the middle of the twentieth century, respectively. American formalists left an identifiable institutional imprint, as evidenced by university programs, professional journals, and trade literature, along with a vast body of work that included pulp fiction novels, screen plays, songs, and journalistic prose.

The task of bringing this body of work to light is further complicated by both its volume (large) and its visibility (obscure). Few of the names I recover here will be familiar to readers. Yet, I will also show that their impact

39. Mark McGurl, The Program Era: Postwar Fiction and the Rise of Creative Writing (Cambridge, MA: Harvard University Press, 2011), 23.

40. E. H. Gombrich, Art and Illusion: A Study in the Psychology of Pictorial Representation, millennium ed., with a new preface by the author (Princeton University Press, 2000), 119, 126. 
on the development of American letters was significant. To do that, I will concentrate on several works representative of the formalist movement as a whole. I will use each as a springboard into parallel texts and contexts, which in aggregate evidence intellectual as well as institutional cohesion. These texts are tightly integrated in that they not only cite each other but also appear on the pages of the same journals and from the same presses, as part of concerted marketing campaigns, written by authors engaged in a common project of professionalization.

\section{FICTION FACTORY BY JOHN EDWARDS}

In his 1846 essay "Philosophy of Composition," Edgar Allan Poe lamented, perhaps with a hint of irony, about the dearth of professional literary publications:

I have often thought how interesting a magazine paper might be written by any author who would - that is to say, who could - detail, step by step, the processes by which any one of his compositions attained its ultimate point of completion. Why such a paper has never been given to the world, I am much at a loss to say-but, perhaps, the autorial vanity has had more to do with the omission than any one other cause. Most writers - poets in especial - prefer having it understood that they compose by a species of fine frenzy - an ecstatic intuitionand would positively shudder at letting the public take a peep behind the scenes, at the elaborate and vacillating crudities of thought - at the true purposes seized only at the last moment - at the innumerable glimpses of idea that arrived not at the maturity of full view-at the fully matured fancies discarded in despair as unmanageable - at the cautious selections and rejections - at the painful erasures and interpolations - in a word, at the wheels and pinions - the tackle for sceneshifting - the step-ladders and demon-traps - the cock's feathers, the red paint and the black patches, which, in ninety-nine cases out of the hundred, constitute the properties of the literary histrio. ${ }^{41}$

Writing his own careful manual for aspiring dramaturges in 1912, the Scottish theater critic William Archer warned against the rampant "pedantry and quackery" found in the burgeoning writers' aids market. "How comes it, then, that there is a constant demand for text-books of the art and craft of drama? How comes it that so many people - and I among the numberwho could not write a play to save their lives, are eager to show others how to do so?" ${ }^{42}$ By 1937, Carleton Brown, a contributor to the Esquire

41. Edgar Allan Poe, "The Philosophy of Composition," Graham's Magazine 28 (April 1846): 163.

42. William Archer, Play-Making: A Manual of Craftsmanship (Boston: Small, Maynard, 1912), 4-6. 
magazine, would write: "My desk is snowed under with the literature of countless correspondence schools which promise to make writing ability grow in the most barren of fields." He continued: "One may learn to crochet, sing, dance, play the zither, become a hotel manager, a civil servant, an osteopath, a cartoonist, a mental giant, or practically anything by mail, but the drive toward converting every man, woman, and child into an author is the most concerted of them all. The time is rapidly approaching when every last one of us will be manufacturing more reading matter than he and his family can possibly read." ${ }^{43}$ The contrast between Poe, Archer, and Brown identifies a major reconfiguration in the structure of the literary sphere, transpiring in the scope of mere decades. Poe wished for someone - anyone - to write about literary technique. Fifty years later, technique was overwhelmingly in vogue.

American formalists differed from their predecessors and their Continental contemporaries in their emphasis on the craft of writing as a faculty capable of being trained, improved, and transmitted. Individuated genius was, at the cusp of the century, a well-worn trope of Romanticism, which passed into high modernist sensibilities with little alteration. Edward Young's "Conjectures on Original Composition” for instance, represents, in the tradition of English letters, a quintessential account of "true genius," which "differs from a good understanding, as a magician from a good architect." This natural and divine force "raises his structure by means invisible," in unstudied liberty, suspicious of "rigid rules" and "famed examples." "For unprescribed beauties, and unexampled excellence, which are characteristic of genius, lie without the pale of learning's authorities, and laws," Young explained. "For rules, like crutches, are needful aid to the lame, though an impediment to the strong. ... There is something in poetry beyond prose-reason; there are mysteries in it not to be explained, but admired, which render mere prose-men infidels to their divinity." ${ }^{4}$ Samuel Coleridge expressed a similar sentiment when he wrote: "There is in genius itself an unconscious activity," manifesting in the "unspoken language [of ] endless compositions." Coleridge's divinely inspired, true, "organic" artists were meant to transcend what he called the "lifeless technical rules" and "cold notions" of mere imitation. ${ }^{45}$ In the 1930s, Mary Colum, the great modernist literary critic, objected to Aristotle's attempts to systematize literary creation much on the same grounds, asserting that his Poetics read as if written by an "intelligent, but not very artistic statesman, whose tastes

43. Carleton Brown, "Who Says You Can't Write?," Esquire, March 1937, 94.

44. Edward Young, "Conjectures on Original Composition," in The Complete Works, Poetry and Prose, of the Rev. Edward Young, vol. 2 (London, 1854), 556-57.

45. Samuel Taylor Coleridge, The Complete Works of Samuel Taylor Coleridge: With an Introductory Essay upon His Philosophical and Theological Opinions (New York, 1858), 332-33. 
inclined to good detective stories and melodrama." ${ }^{46}$ Ezra Pound mirrored that sentiment in his $A B C$ of Reading, where we find: "The dirtiest book in our language is a quite astute manual telling people how to earn money by writing." Pound perceived the how-to manual as lower than the lowest of genres, the "maximum possible intellectual degradation." ${ }^{47}$ In this climate of genius whisperers, few writers of merit would admit to subscribing to authors' monthlies, much less to writing under their influence.

In contradiction to the prevailing Romanticism, the new Aristotelians argued resolutely against genius. Titles in the emerging writers' aids category evidence the extent of the shift from inspired ingenuity to reasoned craft. Consider, within the fullness of primary sources, the following list of selected works: Skeleton Essays, or Authorship in Outline (1890) by Thomas English; The Technique of the Drama: A Statement of the Principles Involved in the Value of Dramatic Material, in the Construction of Plays, and in Dramatic Criticism (1892) by William Thomas Price; The Genesis of Art-Form: An Essay in Comparative Aesthetics Showing the Identity of the Sources, Methods, and Effects of Composition in Music, Poetry, Painting, Sculpture and Architecture (1893) by George Raymond; The Drama: Its Law and Its Technique (1898) by Elisabeth Morris; a translation of Gustav Freytag's Technique of the Drama printed in 1900 in Chicago by Scott, Foresman, and Company; James Knapp Reeves's Practical Authorship (1900); The Technique of the Novel: The Elements of the Art, Their Evolution and Present Use (1908) by Charles Horne; Writing the ShortStory: A Practical Handbook on the Rise, Structure, Writing, and Sale of the Modern Short-Story (1909) by Joseph Esenwein; Harriott Fansler's Types of Prose Narratives: A Text-Book for the Story Writer (1911); Henry Phillips's The Plot of the Short Story (1912) and Art in Short Story Narration (1913); The Technique of the Mystery Story (1913) by Carolyn Wells; The Technique of Play Writing (1915) by Charlton Andrews; Technique of the Photoplay (1916) by Epes Sargent; a translation of Georges Polti's The Thirty-Six Dramatic Situations (1916); The Technique of Fiction Writing (1918) by Robert Saunders Dowst; Dramatic Technique (1919) by George Baker; Plots and Personalities (1922) by Edwin Slosson and June Downey; A Study of Narrative Technique in Folktales of Peoples of Varying Cultures (1926) by Robert Harris; Carl Grabo's The Technique of the Novel (1928); and William Wallace Cook's Plotto: A New Method of Plot Suggestion for Writers of Creative Fiction (1928). A writer's desk was beginning to resemble less a spiritual sanctuary and more a workshop bench or a workstation at an assembly plant.

46. Mary Colum, "Literature, Ethics, and the Knights of Good Sense," Scribner's Magazine 87 (July 1930): 601.

47. See Ezra Pound, ABC of Reading (New York: New Directions, 2010), 89, quoted in Bob Perelman, The Trouble with Genius: Reading Pound, Joyce, Stein, and Zukofsky (Berkeley: University of California Press, 1994), 56. 
"A writer is neither better nor worse than any other man who happens to be in trade," wrote the author of Fiction Factory (1912) and Plotto, the former under the pseudonym of John Milton Edwards in 1912. Authors should view themselves as manufacturers, he argued. After "gathering his raw product," an author "puts it through the mill of his imagination" and "if the product is good, it passes at face value" to become a "medium of exchange," that is, a commodity. ${ }^{48}$ No aspect of the writing process was sacrosanct at the factory. To keep track of his many manuscripts and submissions to editors Edwards proposed a system of record keeping in which every manuscript was numbered. "About the year 1900 card indexes came into vogue, and now a box of cards is sufficient for keeping track of a thousand manuscripts," Edwards explained (28). He went as far as to standardize his stationary, using paper of a uniform size and weight to facilitate postage and to recycle - put back into circulation-rejected manuscripts more efficiently.

The collection of raw material for his prose received the same systematic, industrial treatment. Like other realist authors, notably Dickens and Dostoevsky, Edwards was inspired by news gossip and crime columns. ${ }^{49}$ Early in his career, he began collecting newspaper clippings, at first haphazardly, "thrown loosely into into a large box." By the 1890s, he had hired an assistant to alphabetize and file each clipping, using "large manila envelopes," in effect creating a curated database of material, including metadata printed on the back of each envelope (64). Even this filing system strained under the weight of collected material. In 1905, Edwards developed a system of color codes to organize the collection by subject using index cards.

These improved cards were still neither cross-referenced nor collated. Edwards wrote: "To exhaust [my] material on Booker T. Washington, it was necessary for [me] to hunt through all the pages under 'W,' and then examine all the magazines containing the articles in which he was mentioned" (65-66). Ideally, the various articles should have been grouped together. It subsequently took Edwards two years to cross-reference and catalog the material. He described his improved system as follows (writing about himself in the third person):

48. John Milton Edwards [William Wallace Cook], The Fiction Factory: Being the Experience of a Writer Who, for Twenty-Two Years, Has Kept a Story-Mill Grinding Successfully (Ridgewood, NJ: Editor, 1912), 24; subsequent references are given parenthetically.

49. On Dostoevsky's use of gossip see Donald Fanger, "Dostoevsky's Early Feuilletons: Approaches to a Myth of the City," Slavic Review 22, no. 3 (September 1963): 469-82; and Gary Saul Morson, The Boundaries of Genre: Dostoevsky's Diary of a Writer and the Traditions of Literary Utopia (Evanston, IL: Northwestern University Press, 1988). For gossip in Russian modernism see Stephen C. Hutchings, Russian Modernism: The Transfiouration of the Evervdav (Cambridge University Press, 1997). 
His first step was to buy a number of strong box letter-files. These he numbered consecutively, just as he had numbered the manila envelopes. Articles are cut from magazines, the leaves secured together with brass fasteners, and on the first page margin at the top are marked with the file number and letter of compartment where the article belongs. Thus, if the article is kept out of the file for any length of time it can be readily returned to its proper place. ... The card-index has its divisions and sub-divisions. Card indexing articles on various countries have a place under the general letter, and another place in the geographical section under the same letter. (66)

He further included a facsimile of a sample index card "for the benefit of those wishing to replicate his methods" (fig. 1). "In this system the character of the material [referring to the reproduced card] is first indicated as Pay of Soldiers," Edwards explained. "If there is a title it follows in quotation marks. Where the title suggests the character of the material sufficiently, the title comes first, in 'quotes'. Then follows the letter under which the article is filed, and the number of the file. Suppose it is desired to to find out what soldiers of the United States' Army are paid for their services: File No. 2 is removed from the shelf, opened at letter "Y" and the information secured under the title beginning, "Young Man —" (67).

It would be easy to dismiss such prosaic descriptions of the writing process as mere "shop talk" or, worse yet, as solipsistic reminiscences of a selfprofessed hack. The Fiction Factory did embody an important aspect of the industrial zeitgeist, however. Along with similar volumes, the manual continues to be valuable at least for the historical sociology of literature. We know, for example, that index cards (also known as flash or note cards) later became a staple of high modernism, enough so for the Pulitzer Prize

\section{ARMY, U. S.}
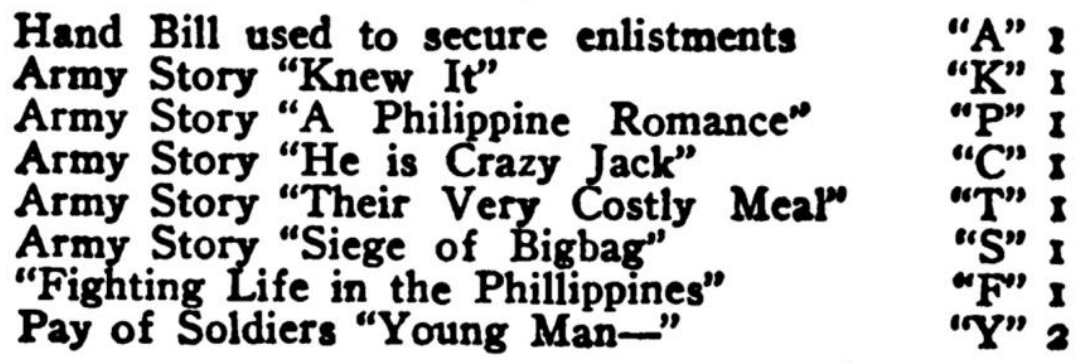

Figure 1. Sample index card from John Milton Edwards, The Fiction Factory: Being the Experience of a Writer Who, for Twenty-Two Years, Has Kept a Story-Mill Grinding Successfully (Ridgewood, NJ: Editor, 1912), 66. 
recipient W. D. Snodgrass to call T. S. Eliot "a kind of flash card machine." Vladimir Nabokov used index cards to aid in the composition of both Pale Fire and Lolita. ${ }^{51}$ The prescriptions found in Edwards's Fiction Factory show that index card use was not limited to a few exceptional "innovators," but rather constituted a commonplace technique of literary composition, used for both information gathering and plot construction by many contemporary writers.

These methods were shared widely in professional publications such as the Editor, founded by James Knapp Reeve in 1895 and billed as "the journal of information for literary workers"; the Author, out of Boston, Massachusetts, founded in 1889 and described as "a monthly magazine to interest and help all literary workers"; the Writer, also out of Boston, established in 1887 and still active today; the Writer's Monthly (1925), affiliated with the Home Correspondence School in Springfield, Massachusetts; Pennsylvania's Writer's Review (1925); Markets and Methods for Writers (1925) by the Palmer Institute of Authorship, a correspondence school out of Hollywood, California; and New York's Author's Digest (1927). Columns printed in these journals and their associated documents - books, pamphlets, and course materials — were by no means limited to secretarial advice related to the management of information or paper products. The Writer, for example, also included book reviews, a digest of "literary articles and periodicals," English usage guides such as "The Use and the Misuse of Words," personal gossip on the lives of major literary figures, various how-to manuals such as the "How to Write a Story of Boys" and "How to Cover a Yacht Race," along with detailed treatments of narrative, versification, and plot structure. This stress on composition represents a kind of early structuralism in reverse. Unlike their Russian or French counterparts, who derived structure from existing literary works inductively, usually for the purpose of scholarly analysis, the Americans arrived at it through deduction, to aid in the creation of new works. The former were scholarly analytic movements and the latter a practice of combinatorial poetics.

\section{ART IN SHORT STORY NARRATION BY HENRY PHILLIPS}

"This has been the assumption on the part of some of [my] book reviewers, that I have been taking undue liberties with a certain Divine Right. Writing of Fiction, they contend, is governed by Unwritten Laws. Technique in this

50. Marjorie G. Perloff, "Realism and the Confessional Mode of Robert Lowell," Contemporary Literature 11, no. 4 (Autumn 1970): 473.

51. Brian Boyd, Vladimir Nabokov: The American Years (Princeton University Press, 1993), 417; and Duncan White, Nabokov and His Books: Between Late Modernism and the Literarv Marketplace (Oxford University Press, 2017), 211. 
profession, I am warned, is God-given. ${ }^{\text {"52 }}$ So wrote Henry Phillips - a career journalist, editor, and lecturer - in the introduction to his Art In Short Story Narration (1913), which he described as "a searching analysis of the qualifications of fiction in general, and of the short story in particular, with copious examples, making the work a practical treatise." 53

Phillips and his fellow travelers shared a professional as well as an intellectual bond. These men and women usually hailed from places peripheral to the literary mainstream, such as Brooklyn, Cincinnati, Louisville, Pittsburgh, Philadelphia, and San Francisco. They were for the most part working writers, contributing to their local papers or selling manuscripts by post to upmarket presses in New York and Los Angeles. Phillips's long career in letters included lecturing at the Brooklyn Academy of Arts, editing the Metropolitan Magazine, and covering Eastern Europe and East Asia (in the field) for the New York Herald Tribune. Among his practical treatments of fiction were popular books on travel and politics including White Elephants in the Caribbean (1917), Meet the Germans (1929), Meet the Japanese (1932), New Designs for Old Mexico (1939), and Argentina: Pivot of Pan-American Peace (1944).

One can hear the echoes of class distinction in the reviews of Phillips's prose. In regard to Meet the Germans, one reviewer asserted that unlike other travel writers, "Mr. Phillips does not try to give the impression, which is so common in writers and others, that he hobnobbed with the great. In fact, the greatest criticism which may be made of the book is that this man seems to know only the mediocre German and the German en masse." ${ }^{4}$ Another reviewer, discussing one of Phillips's earliest how-to guides - on the photodrama "with complete photoplay and a glossary" - wrote about his surprise in finding an author "of the skill and repute" of Henry Phillips writing an elaborate book on such an insignificant topic. It was "amazing and amusing" to see "how seriously the moving picture people took to their calling," he gibed. ${ }^{55}$ Speaking before the Modern Language Association in 1936, Carl Dahlström, a scholar of Scandinavian literature at the University of Michigan, would conclude that the "scoffing and the scorn" placed the subject of formal plot analysis, of the kind found in Art in Short Story Narration, "in the category of untouchables." 56

52. Henry Albert Phillips, Art in Short Story Narration: A Practical Treatise (Larchmont, NY: Stanhope-Dodge, 1913), xi.

53. Ibid., title sheet.

54. C. H. Handschin, review of Meet the Germans, by Henry Albert Phillips, Modern Language Iournal 14, no. 7 (April 1930): 585.

55. J. Stuart Blackton, review of The Photo Drama: With Complete Photoplay and a Glossary, by Henry Albert Phillips, Journal of Education 80, no. 17 (November 1914): 469.

56. Carl E. W. L. Dahlström, "The Analysis of Literary Situation," PMLA 51, no. 3 (September 1936): 875 . 
Such downbeat commentary was typical of the period. At its best, academic reception of American formalism was characterized by bemused condescension; at its worst, outright hostility. There was, for some, something unsavory in exposing how the sausage is made. These were a group of successful, working authors and academics who, unlike many critics of the time, chose to forego the moral and the aesthetic aspects of art in favor of the technical, the commercial, and the scientific. They were interested in revealing the unspoken mysteries of literary genius, showing that its beauty also contained a considerable amount of blood and guts - index cards, stamped envelopes, and rejection letters.

This emerging collective of writers heralded the changing demography of the writing public. A living was to be had in the expanding literary market. But to make a living, one also had to stop browbeating the audience. American formalists approached their calling with candor, acknowledging freely that Literature did not always edify: often it merely entertained, and sometimes, such entertainment could also be elevated into an art. The pendulum of literary fashion swung from a Platonic vision of art - which banished pleasure in favor of truth and which was meant for the golden races - to the Aristotelian, which could concern itself simply and without guilt with the mechanics of an effective diversion.

\section{HARRIOTT FANSLER'S TYPES OF PROSE NARRATIVES}

In their emphasis on reproducible technique, the American school anticipated many of the theoretical insights traditionally associated with Russian formalism and later with French structuralism. Take for example Types of Prose Narratives, a "textbook for the story writer" by Harriott Ely Fansler, who taught English literature first at Western Reserve in Cleveland, Ohio, and then at the University of the Philippines, Manila. ${ }^{57}$ Fansler studied at Columbia University's Department of English and Comparative Literature, under the advisement of Ashley Horace Thorndike, William Peterfield Trent, and Jefferson Butler Fletcher. Her dissertation title, "The Evolution of Technic in Elizabethan Tragedy," piqued my interest because in the historiography of literary studies the term "technique" is strongly associated with the work of Viktor Shklovsky and the Saint Petersburg Society for the Study of Poetic Language (OPOYAZ). This circle of Russian formalists counted among its members Boris Eikhenbaum, Osip Brik, and Yury Tynianov. Their work was, in fact, contemporaneous with Fansler's.

Fansler published Types of Prose Narratives before finishing her dissertation, in 1911, probably while in Manila. One hears in her work a sense of

57. Harriott Ely Fansler, Types of Prose Narratives: A Text-Book for the Story Writer (Chicago: Row, Peterson, 1911), title page; subsequent references are given parenthetically. 
isolation from the research community but also a clarity of purpose that comes with experience and with a shift in perspectives. She opened her monograph, like many others in my archive, with a caution against genius: "There is a popular misconception, especially in the minds of young people and seemingly in the minds of many teachers and critics of literature, that geniuses have sprung full-worded from the brain of Jove and have worked without antecedents. There could not be to a writer a more cramping idea than that. It is the aim of the present volume to help dispel that illusion, and to set in a convenient form before students of narrative the twofold inspiration mentioned - a feeling for the past and a series of definite problems" (v). The "definite problems" on her desk were the variety of written and oral traditions. In the Philippines, Fansler reports being exposed to the rich mythology of Filipino storytelling. She was also almost certainly familiar with James Frazer's seminal work on the comparative study of mythology, The Golden Bough (1890), which was listed in the Columbia library catalog as early as 1908, when Fansler was still on campus. ${ }^{58}$

Fansler's training in comparative literature prepared her to notice patterns and similarities across cultures. "Every race, every nation, every tribe, every family has its favorite narratives," she remarked (xxi). Moreover, she postulated that these narratives fell into "forms inherent to all literatures," but this insight was not presented as a "scientific discovery" in the manner of Propp or Levi-Strauss. "I have not had the benefit of other texts on the subject (for there are none that I know of)," Fansler wrote with characteristic restraint. Instead, she compiled her "narrative types with composition in view," and therefore wanted to exclude the "dogma" of grand theory. For her, it was merely "pleasant to know that there are definite types of narratives that the world has always loved" (xxiii). More than a decade later Propp expressed a similar sentiment: "Just as all rivers flow into the sea, all questions relating to the study of tales lead to the solution of the highly important and as yet unresolved problem of the similarity of tales throughout the world." ${ }^{59}$ Although Fansler did not quite arrive at the "vagabond formulas" by which such analytical universal "constants" of myth are combined, in the way Propp did, she produced a convincing hierarchical taxonomy of her material, composed of meta- and subcategories, which suggested a broadly universal cognitive affinity for specific storylines. For example, her "Narratives of Imaginary Events" included the "SymbolicDidactic Group" and the "Ingenious-Astonishing Group." The latter Fansler further divided into "Tales of Mere Wonder," "Imaginary Voyages with a

58. I extend my gratitude to Sarah Witte of Butler Library for confirming the date of acquisition.

59. Propp, Morphology of the Folktale, 16. 
Satiric or Instructive Purpose," "Tales of Scientific Discovery and of Mechanical Invention," and "The Detective Story and Other Tales of Pure Plot" (xii).

Fansler also understood the limits of her classification system, which, like all classification, was reductive. It imposed the structure of discrete categories onto a continuous, living, and amorphous phenomenon. Why should there be seven major plot structures and not, say, three or thirty-six? How does one classify narratives that span multiple analytic dimensions - for example, a romance tale that contains also elements of an adventure, a mystery, and an escape? "Of course, the types fade into one another," Fansler observed. It is only in analysis that we draw hard and fast distinctions. The categories are merely convenient to build what she called a "working model" of "pure examples," useful for "criticism or further production" (xxv). Unlike many of the structuralists who claimed to "discover" hidden laws that govern all stories universally, Fansler acknowledged the instrumental nature of her taxonomies. For this reason, her studies today seem more nuanced and more sophisticated than the work of those scholars who imbued their "discoveries" with a near-deterministic force.

\section{WILLIAM PRICE'S THE ANALYSIS OF PLAY CONSTRUCTION}

Another advocate of formal methods who took his cues from the Poetics was William Thompson Price, a Kentucky-born Aristotle, ${ }^{60}$ publisher, founder, and chief contributor to the American Playwright (1912-15), as well as the author of The Technique of the Drama (Brentano's Bookstore, 1892) and The Analysis of Play Construction (W. T. Price Publisher, 1908). Price is a curiosity among the coterie I have assembled under the American school in that he was primarily a playreader, whose duties at a theater production company, not unlike those of an editor at a publishing house, involved the review of submitted manuscripts. His impetus for writing a how-to manual stemmed from the hundreds of doubtlessly terrible dramas that moved across his desk every year, many penned by authors who claimed to be natural talents in no need of editorial assistance. "It was the bottomless pit," Price complained. Instead of repeating himself in numerous rejection letters, he wrote a practical textbook "suitable for a workshop." In addition to learning from the greats, he derived his insight from the analysis of "thousands of plays by amateurs." The study of "false dramatic syntax" and

60. In Price's obituary we read: "This man was not a writer of plays and neither was Aristotle, who searched the first little group of basic principles which Mr. Price two thousand years and more afterward was to enlarge, correlate, and define" (Edmund Watson Taylor and editors, "William Thompson Price," Register of Kentucky State Historical Society 20, no. 58 [1922]: 59). Also: "His conception of art of Aristotle who held that the imitative arts serve 'the ends of noble pleasure and relaxation'" (66). 
other deficiencies common to beginners thus became an important component of Price's method. ${ }^{61}$

Price's efforts to vitalize the formal instruction in basic playwriting in the United States had an unexpected impact. The North American Review mentioned his Technique of the Drama as one of the three essential books taught at Harvard, as part of a course called "The Technique of Drama," listed in the bulletin for the first time in 1905 as English 47 and taught by George Pierce Baker, professor of dramatic literature. ${ }^{62}$ In 1919, Baker authored a Dramatic Technique of his own and published it with the comparatively more upmarket (than Brentano's, where Price first published) Houghton Mifflin Company. Baker's version supplanted Price in his syllabi and bore a striking resemblance to the earlier works by Price, unfortunately without attribution. His introduction, like Price's, spoke in favor of learning over talent. Both books contained similar treatments of dramatic action, emotion, plot, characterization, and dialogue.

In a glowing endorsement of the Harvard course, the North American Review reported that it "created a sensation in college and theatrical world," where it was "asserted that play-writing could not be taught." ${ }^{63}$ Playwrights were born not made! English 47 was initially met with wide disapproval, within and without the university. What started as a course on the history of English drama (initially listed as English 14) became a course on playwriting. Baker lobbied the department to allow his students to write original plays instead of essays as part of the course requirements. It was considered a sensationalist move: professional theater people - actors, managers, and playwrights - ridiculed the idea and "made merry jests" about a "high-brow professor at Harvard who is trying to teach college boys and girls how to write plays." 64

But the ridicule could not persist in light of the workshop's obvious success. Already during its first year English 47 produced several popular and well-reviewed plays, including Salvation Nell by Edward Sheldon. The play ran on Broadway, featuring Minnie Maddern Fiske, a star of the stage at the time. In 1915, it was adopted for the screen under the direction of

61. William Thompson Price, The Analysis of Play Construction and Dramatic Principle (New York: Price, 1908), v-vi; subsequent references are given parenthetically.

62. Lafayette McLaws, “A Master of Playwrights," North American Review 200, no. 706 (September 1914): 459-67. See also "The Study of Drama at Harvard," Harvard Alumni Bulletin, January 10, 1912; and Shannon Jackson, Professing Performance: Theatre in the Academv from Philology to Performativity (Cambridge University Press, 2004), 69. In 1917, Baker also assigned Freytag's The Technique of the Drama, Archer's Play-Making, Brander Matthews's A Study of the Drama (1910), Aristotle's Poetics, and Polti's Thirty-Six Dramatic Situations as part of his English 30 course.

63. McLaws, "Master of Playwrights," 465.

64. Ibid. 
Alex Beyfuss by the California Motion Picture Company. ${ }^{65}$ Baker's student Josephine Preston Peabody won the Stratford-on-Avon Prize in England for her play The Piper, which subsequently had a popular run at Boston's New Theater. The American poet and playwright Percy MacKaye, another one of Baker's students, wrote The Scarecrow in 1908 and Anti-matrimony in 1910, under the influence of the course. Another student, Florence Lincoln, won the John Craig Harvard-Radcliffe Prize for her play The End of the Bridge. It ran at Boston's Castle Square Theater, where it was so well received that the theater canceled its other contracts to extend the play's run to nine weeks. ${ }^{66}$ The class also yielded Believe Me, Xantippe by Frederick Ballard, which ran for ten weeks at Castle Square, moved to Broadway with John Barrymore in lead, and was later made into a silent film produced by Jesse Lesky for Paramount Pictures (incidentally, launching the acting career of Ann Little, who became a major star of silent Westerns). The academic world, Broadway, and Hollywood took note.

Both Price and Baker began their books with a discussion of talent. The very notion of technique, characteristic of the school, was predicated on the idea of method: positing the existence of rules and laws that could be discovered, articulated explicitly, and transmitted to others. Unencumbered by academic conventions, Price resorted to impassioned polemics: "Those people who think they have genius, and imagine that man is everything, are misguided egotists. They ignore, or pretend to ignore, the existence of Technique, or they may contend that technique is an indefinable thing and personal and private property. They even think that they have created Material. They are all wrong. Technique is what shapes the Material" (4).

The postulate of technique led the formalists to a natural analogy with the "hard" sciences. The scientific method required talent and diligence, but it was for them, above all, a reproducible technique, which could be learned by anybody through apprenticeship. "He has no instincts that are not shared by every other human being in a greater or less degree," Price insisted (8). Chemists are not born, they are trained and certified. Numerous textbooks are devoted to the subject of training and certification of chemists. Why not literature? Price challenged his readers. Like science, art strives to produce innovative forms, but how can one be born with knowledge of something new and not yet discovered? "By what biological process could you be born a chemist?" Price asked. Novelty itself must have been produced "in chemical fusion" between innate abilities, raw material, and technique. ${ }^{67}$

65. Kevin Lewis, "A World across from Broadway II: Filmography of the World Film Corporation, 1913-1922,” Film History 1, no. 2 (1987): 169.

66. McLaws, "Master of Playwrights," 466.

67. W. T. Price, "The Common Sense of Dramatic Law as Applied to the Affairs of Life," American Playwright 1, no. 1 (January 1912): 3-8. 
The reproducible character of technique - the belief in the capacity of every human to receive knowledge - related to the possibility of discovering universal laws that guide artistic creation. "While Playwriting is an art," Price wrote, "it is an art in the nature of an exact science. As a science it had certain fundamental truths, which, like the axioms in geometry must be accepted as a necessary prerequisite to proper understanding of the art" (17). A literary work was therefore amenable to atomic analysis: it could be broken down into parts to reveal patterns that repeated regularly across texts. "There is a certain mechanism about playwriting that is just as distinct as the mechanism of a watch," Price argued. And to understand how a watch is made, one had to "ascertain the relations of its various parts" (9). In a work of art, these relations were ultimately distinct from the qualities of morality or beauty. Ethics and aesthetics changed with the time-technique remained eternal. "It will never become old fashioned," he concluded (13-14).

Baker defined technique even more succinctly, as "ways, methods, and devices" for achieving the desired dramatic results. ${ }^{68}$ His history of drama was cast in evolutionary terms, similar to Fansler's Evolution of Technic in Elizabethan Tragedy (1914). For his part, Baker differentiated between three types of technique: universal, special, and individual. Universal technique identified general rules of composition common to all people and periods. Special technique defined a specific period, in which certain forms dominated at the expense of others. In this way, the classicism of the early nineteenth century gave way to Romanticism and later modernism. Finally, an individual developed devices particular to his or her own style, which diverged both from universal law and from the fashion of the times. Technique in this universal sense could become the subject of study and transmission, where its individual manifestations developed idiosyncratically and were instead a matter of talent and sensibility. ${ }^{69}$

\section{THE TECHNIQUE OF THE MYSTERY STORY BY CAROLYN WELLS}

In addition to their emphasis on transmittable technique, American formalists consistently shifted emphasis from art as a vehicle of edification to art as entertainment. "Accuracy, in spite of the derision in which Technique is sometimes held, means truth," Price observed. "There is also money in it" (12). Under systematic evaluation, abstract literary forms were found to contain many mundane yet important aspects of craft, which lead from a writer's desk to the editor's and from there to bookstore aisle.

68. George Pierce Baker, Dramatic Technique (New York: Houghton Mifflin, 1919), 1.

69. Ibid., 3-6. On the more general context of institutionalization of English programs at Yale and Brown Universities, see Robert Scholes, Rise and Fall of English: Reconstructing English as a Discipline (New Haven, CT: Yale University Press, 1998), 1-28. 
Carolyn Wells published her Technique of the Mystery Story with the Home Correspondence School in 1913, where it was sold alongside such titles as The Art of Versification, "a complete manual for writers of verse" by J. Berg Esenwein and Mary Eleanor Roberts; The Art of Story-Writing; Manuscript Preparation; and Writing the Photoplay. ${ }^{70}$ Wells was the star of the series. By this time, she had achieved international fame as a writer of detective fiction. She contributed to literary magazines such as the Lark, Philistine, Bibelot, and the Yellow Book and wrote for newspapers in the Midwest and on the East Coast. By the end of her career she was known as the author of 170 novels, including the Fleming Stone, Alan Ford, and Pennington Wise mysteries along with the Patty Fairfield, Marjorie Maynard, and Dorrance Family series of children's stories. ${ }^{71}$

"Why is a detective story?" Wells asked poignantly in her introduction. "To entertain, to interest, to amuse. It has no deeper intent, no more subtle raison d'etre than to give pleasure to its readers" (1). The detective story was particularly susceptible to formal methods because the genre itself was governed by the logic of analytical reasoning. Wells took more than a few pages to defend detective fiction against charges of vulgarity. When written skillfully, it could become "primarily and integrally" a work of art. "Mark how the cover fits," she wrote, "how smooth is the working of that spring drawer. Observe that this bit of carving, which seemed mere ornament, is really a vital part of the mechanism" (15).

The detective story stands accused of being mechanical, and it is so, Wells admitted. But, don't other forms of art also follow rigid procedures? Take a sonnet or a sestina, for example. Who denies their beauty? she asserted. The same dynamic between the mechanical and the sublime held true for architecture, sculpture, and mosaics: "The Heraldic lions in front of the New York Public Library may not be true to nature's lions, may not be true to a poetic imagination of a lion, but they are true to the laws of the conventional lion of heraldry, and are therefore art" (15-16). Like most of her peers in the how-to genre, Wells discussed a number of literary examples, ancient and modern, to develop a system of classification, which, in the case of mystery literature, included "Ghost Stories," "Riddle Stories," and "Detective Stories." Three chapters of her Technique were devoted to "devious devices": footprints and fingerprints, tabulated clues, and the use of disguise.

Wells also allotted several sections in her book to plot structure. "The single plot that makes a Detective Story may be likened to an accordion; it may be pulled out to an extraordinary length, or compressed to a minimum,"

70. Carolyn Wells, The Technique of the Mystery Story (Springfield, MA: Home Correspondence School, 1913), inside cover; subsequent references are given parenthetically.

71. Joan Wylie Hall, “Carolyn Wells (c. 1862-1942)," Legacy 13, no. 2 (1996): 142-51. 
she remarked (279). Regardless of length, a good detective plot is one in which every detail is subservient to the forward momentum toward a singular destination: the resolution of mystery. The work proceeds step by step, as Edgar Allan Poe once described his writing process, "with the precision and rigid consequence of a mathematical problem." ${ }^{\text {" T2 }}$ To such precise ends, Wells followed her more theoretical passages, which dealt with plot construction, with some practical advice.

The detective story must be architected and not just composed, she wrote, because it requires unity and precision. A detective story writer could use the following heuristic according to her system:

1. Plan original crime, method, and motive of the murderer.

2. Create, with this as a nucleus, sub-plots relating to several persons who by coincidence are drawn to the place or are connected with the victim, in different ways. (297)

These preparatory steps led to a skeleton outline:

1. Introduction.

2. Murder discovery.

3. Then take up the least likely suspect first, followed by others.

4. Hero Detective enters, decides, arrests and explains. (297)

Following the precepts set out by Poe in "The Philosophy of Composition," Wells gave the reader several examples of a "balanced" story, suggesting that an aspiring author may wish to follow the example of Gelett Burgess (author and founding editor of the Lark), who diagrammed his stories visually to achieve a sense of proportion (fig. 2). Her monograph ended with a section in defense of a woman's ability to write detective fiction as popular and clever "as any written by men" (314). A quote from Arlo Bates, another important figure in the American formalist movement, concluded the volume.

Bates wrote the influential Talks on Writing English in two volumes (1896 and 1901). They were based on his courses in Advanced English Composition, given under the auspices of Massachusetts Institute of Technology in Boston, as part of the Lowell Free Lectures series. ${ }^{73}$ Bates's work was often praised and cited in the professional publications I have reviewed here, including frequently in the Writer.

72. Poe, "Philosophy of Composition," 163; Wells, Technique of the Mystery Story, 291.

73. "Lowell Free Lectures," Harvard Crimson, October 1895. Also mentioned in Boston Public Library, Monthly Bulletin of Books Added to the Public Library of the City of Boston, vol. 6 (Boston: Trustees, 1901). 


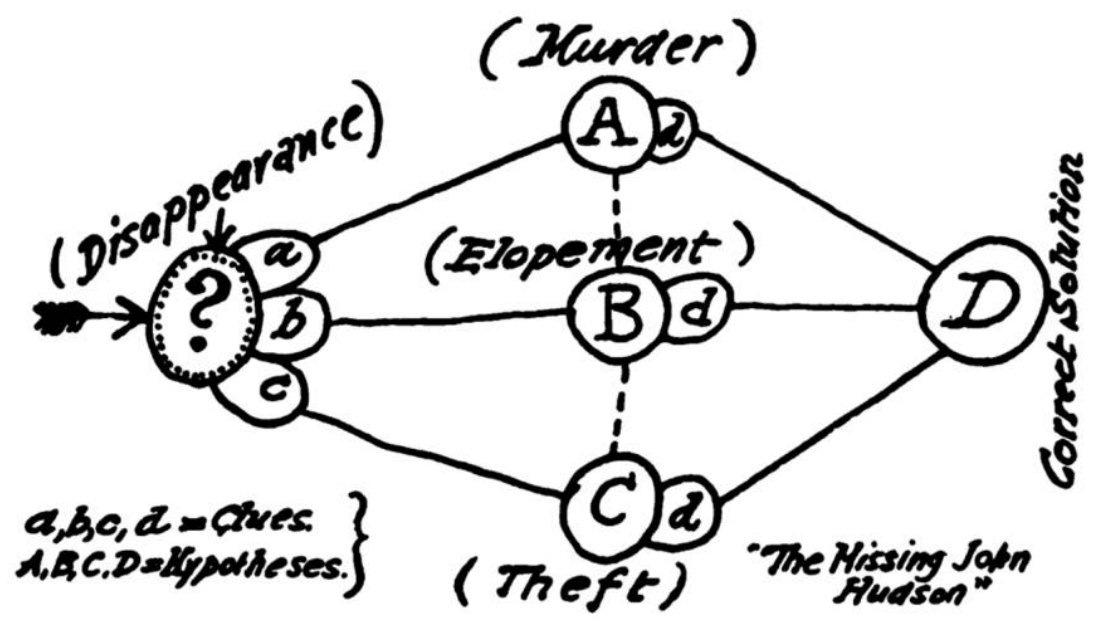

Figure 2. "Mr. Gelett Burgess constructs his stories by architectural diagrams." Carolyn Wells, The Technique of the Mystery Story (Springfield, MA: Home Correspondence School, 1913), 297.

In her own book, Wells made the most use of the passages found in the conclusion of Bates's second volume. No writer can become great without at least passing through the fields of mediocrity, she proclaimed. The fact that many will never be able to transcend such pedestrian vistas should not be a cause of embarrassment for aspiring writers. "Necessity knows no law, and a man may be forced to drudgery with the pen as with the pickaxe," she echoed Bates (326). ${ }^{74}$ The writer who "gives his life to literature as a profession" should be able to look upon the "delight of work" as its own reward: "If he is not able with his whole heart to do this, he is not wise in attempting literature in its higher and more exclusive sense." ${ }^{\prime 75}$

Where others bemoaned the increasing professionalization of the literary arts, Wells and Bates celebrated it. ${ }^{76}$ There is an honest living to be had in what Bates called "the mechanical letters": "the profession of the journalist, the magazine writer, the editor rank with the professions of law or medicine." Craft too could be done for art's sake, he insisted. Unlike the Romantics, Bates and his fellows freely acknowledged the necessity of financial success. The democratization of the literary sphere entailed the professionalization of letters, which could no longer be sustained by

74. See Arlo Bates, Talks on Writing English, vol. 2 (New York: Houghton, Mifflin, 1901), 252.

75. Ibid.

76. "Business is the opprobrium of Literature" (W. D. Howells, "The Man of Letters as a Man of Business," Scribner's Magazine 14 [December 1893]: 429). 
Romantic appeals to the good and the beautiful. A modernist theory of art had to account for the expanding number of men and women for whom literature was a calling and a means of sustenance. ${ }^{77}$

Starting with Polti and finishing with Wells, I have assembled here an archive of documents, almost entirely absent from the scholarly record, which nevertheless evinces a remarkably coherent school of thought. That school was characterized first by its emphasis on technique and by the development of a formal, analytical approach to the production of texts; and second by its emphasis on skill-based aspects of the writing process, including those elements of print production - typesetting and manuscript submission - not usually discussed in the context of literary theory. The group left a distinct institutional imprint, as evidenced by the instructional materials we have encountered so far. The archive tells a story of a period in American letters that prefigures the institutionalization of creative writing programs described by McGurl and others. The transmission of writing templates - tips and techniques-began in earnest at the turn of the century in the output of numerous professional publications, workshops, and correspondence schools. Finally, we have observed a trend in the trajectory of cultural borrowing that moves counter to the expected narrative of "trickle down" ingenuity, by which a heroic individual artist transforms his times through sheer force of will and creativity. The formal methods I have identified here-from the use of flash cards by Edwards to the classification schemas of Price and Baker-advanced in small increments and communally. Rather than trickling down, they tended to emanate from "down-market" institutions, up: from free public lectures to the classrooms of Harvard and MIT, from Manila to Cambridge, and from the card catalogs of a fiction factory to the writing desks of high modernism.

77. Christopher Hilliard has suggested we consider similar developments in British letters as part of an amateur author movement "associated with writing magazines, textbooks, correspondence schools, and writers' clubs” (To Exercise Our Talents: The Democratization of Writing in Britain [Cambridge, MA: Harvard University Press, 2006], 4). The democratization of writing as I see it is rather a movement toward broad professionalization. 